\title{
Electrogeneration of Superoxide Ion on Thiophenol-Modified Gold Electrode in Aqueous Solution
}

\author{
Futoshi MATSUMOTO, Koichi TOKUDA and Takeo OHSAKA*
}

Received June 16, 1995 ; Accepted July 28, 1995

\begin{abstract}
1 INTRODUCTION
Superoxide ion $\left(\mathrm{O}_{2}^{-}\right)$is the primary component of the so-called reactive oxygen species(ROS) that are produced in biological respiration and metabolism, and it is believed that this free radical ion may be closely related to a number of biological phenomena such as aging, disease, cancer and inflammation. In an attempt to gain better understanding of the biomolecular reactivity of $\mathrm{O}_{2}^{-}$, we have been investigating its electrochemical and homogeneous redox behavior using molecularly modified electrodes ${ }^{1-5}$ ). This communication reports on the preliminary results concerning the electrogeneration of $\mathrm{O}_{2}{ }^{-}$via one-electron reduction of dioxygen $\mathrm{O}_{2}$ at thiophenol-modified gold electrode in aqueous media.
\end{abstract}

\section{EXPERIMENTAL}

Electrochemical mesurements were performed at laboratory temperature $\left(20 \pm 2{ }^{\circ} \mathrm{C}\right)$ using a BAS $100 \mathrm{~B} / \mathrm{W}$ electrochemical system and a rotating electrode system (Nikko Keisoku Co.). $\mathrm{An} \mathrm{Ag} / \mathrm{AgCl}$ (saturated $\mathrm{KCl}$ ) electrode was used as the reference electrode and a Pt wire as the counter electrode. A gold disk electrode (diameter: $1 \mathrm{~mm}$ ) served as the working electrode. It was, before use, polished with $0.3 \mu \mathrm{m}$ alumina powder (Marumoto Kogyo Co.) on a

Department of Electronic Chemistry, Interdisciplinary Graduate School of Science and Engineering, Tokyo Institute of Technology (Nagatsuta, Midori-ku, Yokohama 226, Japan)

Key Words: Molecular Oxygen, Superoxide Ion, Electrode Surface Modification, Thiophenol microcloth wetted with Milli-Q water, carefully sonicated in water, rinsed with water, and finally airdried. Surface modification was carried out by dipping the freshly polished electrode into a thiophenol/methanol(1/10(volume ratio)) solution for $3 \mathrm{~h}$. Irreversible modification of the surface was checked by measuring double-layer capacitance, which is lower than that of a bare clean Au electrode.

A Hitachi spectrophotometer U-3300 was used along with a quartz cell with light-path length of 1 $\mathrm{cm}$ to measure UV-Vis spectra of the reduced form of cytochrome $c$, which was produced by the redox reaction between its oxidized form and the electrogenerated $\mathrm{O}_{2}^{-}$.

Bovine erythrocyte copper-zinc superoxide dismutase(SOD, 3000 units $\mathrm{mg}^{-1}$ ) and thiophenol were purchased from Wako Pure Chemical Industries. Cytochrome $c$ from horse heart (purity $>99 \%$ ) was obtained from Sigma. Water was purified by passage through a Milli-Q purification train. Other chemicals were of reagent grade and were used as received.

\section{RESULTS AND DISCUSSION}

Figure 1 shows the typical steady-state voltammograms for $\mathrm{O}_{2}$ reduction at the bare and thiophenol-modified rotating disk $\mathrm{Au}$ electrodes in $\mathrm{O}_{2}-$ saturated $0.5 \mathrm{M} \mathrm{KCl}$ solutions containing $0.1 \mathrm{mM}(\mathrm{M}$ $=\mathrm{mol} \mathrm{dm}-3) \mathrm{NaOH}(\mathrm{pH} 10)$ in the absence and presence of SOD. The voltammograms with halfwave potential around $-0.25 \mathrm{~V}$, which were obtained at the unmodified $\mathrm{Au}$ electrode, correspond to the two-electron reduction of $\mathrm{O}_{2}$ to $_{2} \mathrm{H}_{2}$. At the thio- 
phenol-modified Au electrode the voltammograms shifted by ca. $0.2 \mathrm{~V}$ to the negative direction of potential, and at a given electode rotation rate the limiting current $\left(i_{\text {lim }}\right)$ was smaller compared with that at the unmodified electrode. At the thiophenolmodified electrode, an addition of a small amount of SOD enzyme $(0.5 \mu \mathrm{M})$ into the electrolyte solution resulted in a significant increase in $i_{\text {lim }}$, which is likely due to the $\mathrm{O}_{2}{ }^{-}$dismutation(disproportionation) by SOD. SOD is a metallo-enzyme which efficiently catalyzes the dismutation of $\mathrm{O}_{2}^{-}$to $\mathrm{O}_{2}$ and $\mathrm{H}_{2} \mathrm{O}_{2}$ via a cyclic oxidation-reduction mechanism, ${ }^{6}$ )

$$
2 \mathrm{O}_{2}^{-}+\mathrm{H}_{2} \mathrm{O} \longrightarrow \mathrm{H}_{2} \mathrm{O}_{2}+\mathrm{O}_{2}+2 \mathrm{OH}^{-}
$$

The SOD-catalyzed dismutation of $\mathrm{O}_{2}{ }^{-}$is almost diffusion-limited and the reaction rate is independent of $\mathrm{pH}$ in its range from 7 to $9.5^{7}$. Thus, the data in Fig. 1 suggest the electrogeneration of $\mathrm{O}_{2}^{-}$via oneelectron reduction of $\mathrm{O}_{2}$ at the thiophenol-modified

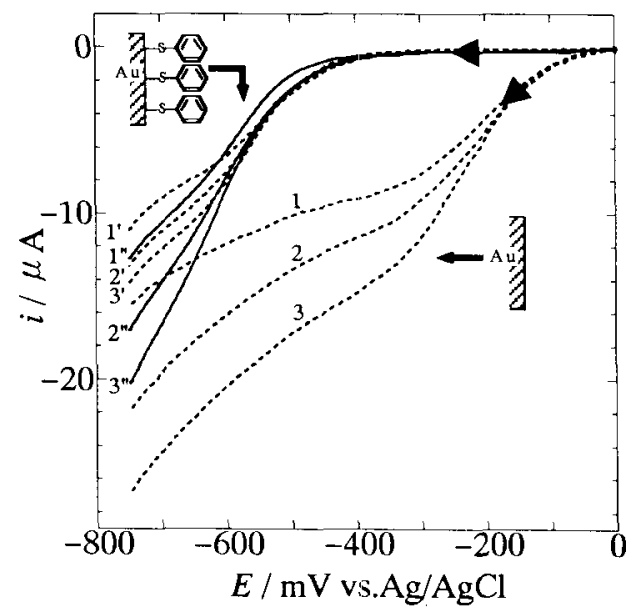

Fig.1 Typical steady-state voltammograms for the $\mathrm{O}_{2}$ reduction at the bare $(1,2,3)$ and thiophenolmodified(1',1",2',2', 3',3") rotating Au disk electrodes in $\mathrm{O}_{2}$-saturated $0.5 \mathrm{M} \mathrm{KCl}+0.1 \mathrm{mM} \mathrm{NaOH}$ solution $(\mathrm{pH} 10)$ in the absence $\left(1,1^{\prime}, 2,2^{\prime}, 3,3^{\prime}\right)$ and presence( $\left(1^{\prime \prime}, 2^{\prime \prime}, 3^{\prime \prime}\right)$ of $0.5 \mu \mathrm{M}$ SOD. Electrode rotation rate: $\left(1,1^{\prime}, 1^{\prime \prime}\right) 400,\left(2,2^{\prime}, 2^{\prime \prime}\right) 900$ and $\left(3,3^{\prime}, 3^{\prime \prime}\right) 1600$ rpm. Potential scan rate: $5 \mathrm{mVs}^{-1}$.
Au electrode. Here it should be noted that the $i_{\text {lim }}$ value obtained at the modified electrode in the $a b-$ sence of SOD exceeds that expected when the $\mathrm{O}_{2}$ reduction moves from two-electron process to oneelectron process (i.e., one half of the $i_{\lim }$ value at the unmodified electrode) by about $30-40 \%$. This excess value is by far too large to correspond to the regeneration of $\mathrm{O}_{2}$ from the $\mathrm{pH}$-dependent spontaneous dismutation of $\mathrm{O}_{2}^{-}$(its rate constant is ca. $10^{3} \mathrm{M}^{-1} \mathrm{~s}^{-1}$ at $\mathrm{pH}\left(0^{8)}\right)^{9}$. The contribution of the spontaneous dismutation of $\mathrm{O}_{2}^{-}$to an increase in $i_{\text {lim }}$ is calculated to be only a few percents at $\mathrm{pH} \mathrm{109}$. Such an excess $i_{\text {lim }}$ value is probably due to the further reduction of $\mathrm{O}_{2}^{-}$with the intervention of water molecule acting as a proton donor:

$$
\mathrm{O}_{2}^{-}+\mathrm{H}_{2} \mathrm{O}+\mathrm{e}^{-} \rightarrow \mathrm{HO}_{2}^{-}+\mathrm{OH}^{-}
$$

as in the case of the electrogeneration of $\mathrm{O}_{2}^{-}$at the mercury electrodes with a hydrophobic adsorption layer of quinoline and its derivatives ${ }^{1-5,10}$. The reaction(2) is thermodynamically more favorable than the first electron-transfer step:

$$
\mathrm{O}_{2}+\mathrm{e}^{-} \rightarrow \mathrm{O}_{2}^{-}
$$

The electrogeneration of $\mathrm{O}_{2}^{-}$at the thiophenolmodified $\mathrm{Au}$ electrode could be confirmed from the observation of the absorption spectra of the ferrous cytochrome $c\left(\right.$ cyt. $c\left(\mathrm{Fe}^{2+}\right)$ ) which is produced by the reduction of its ferric form $\left(\operatorname{cyt} . c\left(\mathrm{Fe}^{3+}\right)\right)$ with $\mathrm{O}_{2}^{-}$;

$$
\text { cyt.c }\left(\mathrm{Fe}^{3+}\right)+\mathrm{O}_{2}^{-} \rightarrow \text { cyt.c }\left(\mathrm{Fe}^{2+}\right)+\mathrm{O}_{2}
$$

This reaction has been widely used for in vitro $\mathrm{O}_{2}^{-}$ assay in which the amount of the produced cyt.c $\left(\mathrm{Fe}^{2+}\right)$ can be sensitively monitored at ca. 550 nim. ${ }^{11)}$ The related experimental results are shown in Fig.2, where the constant potential electrolysis at $-0.5 \mathrm{~V}$ was carried out at the thiophenol-modified rotating disk $\mathrm{Au}$ electrode in $\mathrm{O}_{2}$-saturated $0.5 \mathrm{M} \mathrm{KCl}$ $+0.1 \mathrm{mM} \mathrm{NaOH}$ solution(pH10) containing $1 \mu \mathrm{M}$ cyt.c $\left(\mathrm{Fe}^{3+}\right)$ for $30 \mathrm{~min}$, and then absorption spectra of the electolysis solution were measured. The new specific $\alpha, \beta$ absorption bands around 520 and 550 $\mathrm{nm}$ are significantly larger compared with that in the 


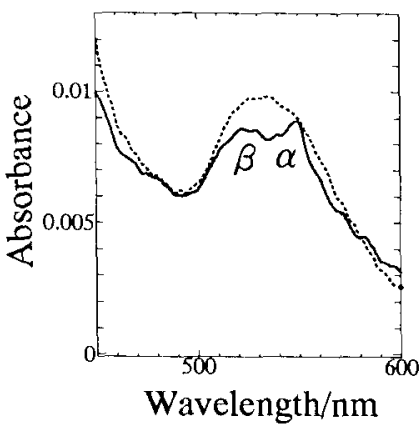

(A)

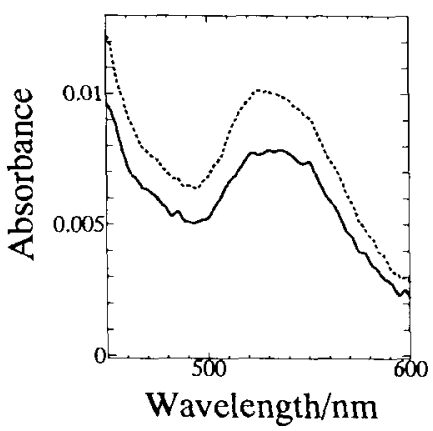

(B)

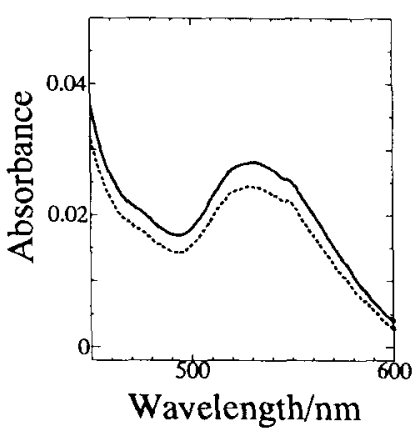

(C)

Fig. 2 Visible absorption spectra of $(A, C) \mathrm{O}_{2}$ or (B) $\mathrm{N}_{2}$-saturated $0.5 \mathrm{M} \mathrm{KCl}+0.1$ $\mathrm{mM} \mathrm{NaOH}$ solution containing cyt.c $\left(\mathrm{Fe}^{3+}\right)((\mathrm{A}, \mathrm{B}) 1 \mu \mathrm{M},(\mathrm{C}) 2.5 \mu \mathrm{M})$ before $(---)$ and after $(\rightarrow$ the electrolysis with $(A, B)$ the thiophenol-modified and $(C)$ unmodified $\mathrm{Au}$ electrodes at $-0.5 \mathrm{~V}$ vs. $\mathrm{Ag} / \mathrm{AgCl}$ for $30 \mathrm{~min}$. The electrode was continuously rotated at $400 \mathrm{rpm}$ during the electrolysis.

blank experiment under $\mathrm{N}_{2}$ atmosphere(Fig.2(B)). In this case, the red shift of Soret band around 415-425 nm was, as expected ${ }^{12)}$, observed (not shown here). The absorption spectrum of Fig.2(A) was essentially the same as that observed for the cyt.c( $\left(\mathrm{Fe}^{2+}\right)$ solution which was prepared by reducing the cyt.c( $\left(\mathrm{Fe}^{3+}\right)$ solution with sodium dithionite. Thus, these facts demonstrate that cyt.c $\left(\mathrm{Fe}^{2+}\right)$ is produced via the mediated reduction of Eq. 4 and that the direct reduction of cyt.c $\left(\mathrm{Fe}^{3+}\right)$ does not actually occur at the thiophenolmodified Au electrode. In addition, it is also obvious from Fig.2(C) that the reduction of cyt.c( $\left(\mathrm{Fe}^{3+}\right)$ by $\mathrm{H}_{2} \mathrm{O}_{2}$, which is produced by two-electron reduction of $\mathrm{O}_{2}$, as well as its direct electrode reduction are almost negligible under the present experimental conditions. Finally, it should be mentioned that the rate constant (ca. $3 \times 10^{-2} \mathrm{M}^{-1} \mathrm{~s}^{-1} 13$ ) ) of the backward reaction of Eq. 4 is smaller about seven orders of magnitude than that $\left(1.5 \times 10^{5} \mathrm{M}^{-1} \mathrm{~s}^{-1}{ }^{14}\right)$ of the forward reduction. The slowness of the oxidation of cyt.c $\left(\mathrm{Fe}^{2+}\right)$ by $\mathrm{O}_{2}$ is very important from the point of view of its role in vivo, because it should react with cytochrome $c$ oxidase but not with $\mathrm{O}_{2}$, which is present in its surroundings.

In conclusion, we could for the first time observe the electrogeneration of $\mathrm{O}_{2}^{-}$via one-electron reduction of $\mathrm{O}_{2}$ at the surface-modified Au electrode in aqueous media. The thiophenol layer on the Au electrode surface is considered to function as a hydrophobic layer which makes difficult the access of water molecules to the electrogenerated $\mathrm{O}_{2}{ }^{-}$ion. The similar studies have been previously carried out exclusively using mercury(or mercury-coated Pt and $\mathrm{Au}$ ) electrodes with hydrophobic surfactants ${ }^{1-5,7,15}$ ) and in the only one case using carbon paste electrodes $^{16)}$. A related study using other electrode surface modifiers is in progress.

The present work was financially supported by a Grant-in-Aid for Scientific Research(No. 05453117) and for Priority Area Research on New Development of Organic Electrochemistry ( Nos.06226222 and 07215221 ) from the Ministry of Education, Science and Culture, Japan, the Nissan Science Foundation, and the Terumo Life Science Foundation. 


\section{References}

1) T. Ohsaka, F. Matsumoto, F. Kitamura and K.Tokuda, Denki Kagaku, 61, 763(1993).

2) T. Ohsaka, F. Matsumoto and K. Tokuda, Frontiers of Reactive Oxygen Species in Biology and Medicine (K. Asada and T. Yoshikawa Eds.), Elsevier Science, p.91(1994).

3) F. Matsumoto, K. Tokuda and T. Ohsaka, Electroanalysis, submitted.

4) F. Matsumoto, T. Okajima, K. Tokuda and T. Ohsaka, J. Deuterium Sci., 3, 95(1993).

5) T. Ohsaka, F. Matsumoto, T. Okajima and K. Tokuda, J. Deuterium Sci., 4, 44(1994).

6) A. M. Michelson, J. M. McCord and I. Fridovich(Eds.), Superoxide and Superoxide Dismutase, Academic Press, New York(1977).

7) S. Marklund, J. Biol. Chem., 251, 7504(1976).

8) B. H. J. Bielski, Photochem. and Photobio., 28, 645(1978).
9) E. F. Orsega, E. Argese, P. Viglino, R. Tomat and A. Rigo, J. Electroanal. Chem., 131, 257(1982).

10) J. Chevalet, F. Roulle, L. Gierst and J. P. Lambert, J. Electroanal. Chem., 39, 201(1972).

11) L. Packer and A. N. Glazer(Eds.), Methods in Enzymology, Vol. 186(1990).

12) E. Margoliash and N. Frohwirt, Biochem. J., 71, 570(1959).

13) Y. Sawada, T. lyanagi and I. Yamazaki, Biochemistry, 14, 3761(1975).

14) M. G. Simic, I. A. Taub, J. Tocci, P. A. Hurwitz, Biochem. Biophys. Res. Commun., 62, 161(1975).

15) B. Kastening and G. Kazemifard, Ber. Bunsenges. Phys. Chem., 74, 551(1970).

16) M. Brezina and A. Hofmanova-Matejkova, J. Electroanal. Chem., 44, 460(1973). 